\title{
Informal public transport driver behaviour and regulatory policy linkage: An expose
}

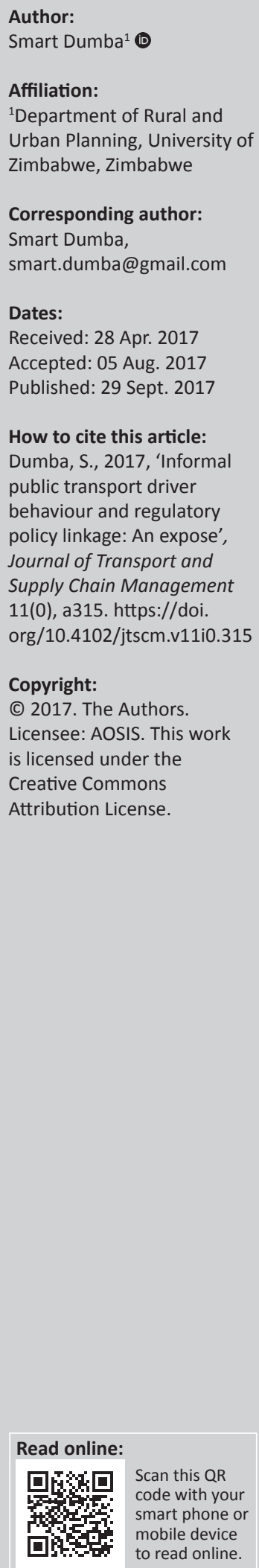

Background: Literature on the negative socio-economic and environmental externalities generated by informal public transport (IPT) in developing countries is vast, vibrant and growing fast. These externalities include but are not limited to noise, air and land pollution, accidents and, more importantly, a source of congestion (human and vehicular) because of poor driver behaviour. In this article, the research does not seek to reinstate these, but rather, it argues that poor driver behaviour is a dependent variable to some regulatory policy stimuli. Yet, an extensive literature survey has shown that the driver behaviour and urban transport regulation linkage remain little explored.

Objective: The purpose of this article was to unpack the relationship between informal public transport driver behaviour and the prevailing regulatory framework.

Method: Based on a case study of Harare, Zimbabwe, the researcher adopted a mixed-methods paradigm and interrogated the prevailing urban public transport regulatory regimes and applied professional judgement, oral interviews backed by some quantitative data and relate these to obtaining IPT driver behavioural characteristics.

Results: Poor driver behaviour exhibited by IPT were generated, exacerbated and or eased by the prevailing regulatory policy. This is well depicted through an IPT driver behaviour and regulation loop reinforcing diagram.

Conclusion: Following this argument, the article cautions policy makers and urban managers alike that direct approaches and interventions when trying to regulate IPT poor driver behaviour and its secondary negative effects will be futile as long as the regulatory policy remains the same. Failure to recognise and connect the dots between IPT driver behaviour and policy partly explains why globally, the IPT sector has proved difficult in prohibiting, restructuring or even formalising it.

\section{Introduction}

The rapid urbanisation in developing countries has led to an unprecedented increase in demand for mobility services (Kumar et al. 2016:102). Syabri, Pradono and Soegijanto (2013) noted that the rapidly increasing demand of paratransit or informal public transport (IPT) in fast-growing cities of developing countries has been confirmed by many as a response to the inadequacy of services, poor management, financial problem and lack of proper maintenance of the conventional public transport system. In generic terms, IPT takes many forms; thus, Losby et al. (2002) posit that defining informal work presents many challenges and perhaps, the only way to define is to identify its characteristics. With this understanding, IPT is commonly defined in terms of how it works especially in the sense of how it does not work like formal transportation (Cities Development Initiative for Asia [CDIA 2011]). Cervero and Golub (2007) define five classes of paratransit services in the developing world that often operate informally, which are shown in Table 1.

As seen from Table 1, IPT takes different modal forms and is known by various local names such as Matatu in Kenya, Dalladalla in Tanzania, Marshrutka in countries of Commonwealth of Independent States, the Baltic states, Bulgaria and Georgia, Jeepney in the Philippines, Angkot in Indonesia, Taxi in South Africa and Minibus or Kombi in Zimbabwe. Some scholarly work has conceptualised IPT as illegal. For example, Cervero and Golub (2007:446) characterised IPT as 'services provided without official sanction ...' CDIA (2011:10) also stated, 'IPT operators lack licenses ...' Kassa (2014:n.p.) defined IPT as the operation that unlawful to the industry. These assertions by Cervero and Golub; CDIA and Kassa may not always be wrong, but they are equally certainly not always right. IPT operators may be registered and recognised at law by the relevant local authority 
TABLE 1: Classes of paratransit vehicles and services that operate informally.

\begin{tabular}{|c|c|c|c|c|c|}
\hline \multirow[t]{2}{*}{ Class } & \multicolumn{2}{|c|}{ Service features } & \multicolumn{3}{|c|}{ Passenger } \\
\hline & Routes & Schedules & Capacity & Service niche & Service coverage \\
\hline Minibus or jitney & Fixed & Semi-fixed & $12-24$ & Mixed & Subregion \\
\hline Microbus or pickup & Fixed & Semi-fixed & $4-11$ & Distribution & Subregion \\
\hline Three wheeler or motorcycle & Variable & Variable & $1-4$ & Feeder & Neighbourhood \\
\hline Pedical or horse cart & Variable & Variable & $1-6$ & Feeder & Neighbourhood \\
\hline
\end{tabular}

Source: Cervero, R., 2000, Informal transport in the developing world, United Nations Commission on Human Settlements, Nairobi, Kenya, 2000

or the parent ministry; this legality status, however, is not a safe net for them to qualify to be labelled formal, they remain informal owing to their operational characteristics that are very different from typical formal public transport systems.

\section{Analytical framework and literature survey}

This study hinges on the argument that driver behaviour especially for kombis and pirate taxis is a response to the prevailing policy at a given time. Dye (1987:1) defines public policy as 'whatever governments choose to do or not do'. Public policy provides a broader framework within which regulation is better understood. It is useful upfront to carefully define key terminology in this article, including the meanings of regulation and institutional framework. The definition cited by Freiberg (2006:2) based on the work of Black (2002) will be adopted in this study. Under this notion, regulation is the sustained and focused attempt to alter the behaviour of others according to defined standards or purposes with the intention of producing a broadly identified outcome or outcomes. Institutional framework is defined by Donnellan, Hanrahan and Hennessy (2012:1) as the systems of formal laws, regulations and procedures, and informal conventions, customs and norms that broaden, mould and restrain socio-economic activity and behaviour. Over the years, the general policy stance of governments on informal transport has been categorised by Cervero (2000) to be from acceptance to prohibition, representing different degrees of regulatory stringency from lax to strict. Other scholars, for example, Golub (2003), have chosen the 'prohibit - ignore or regulate' continuum. Another way of describing the range can be between the 'compel - nurture' extremes. Every point along the spectrum has taxed city authorities to varying levels and has generated different responses from IPT providers. This public transport regulatory continuum determines the way IPT operates and this study zooms in on driver behaviour. Figure 1 presents the spectrum of public policy responses to informal public transportation.

One major distinguishing characteristic of IPT is their operational characteristics. A key operational characteristic is driver behaviour. The typical behaviour of matatus (IPT in Kenya) drivers has been vividly captured by Shorter and Onyancha (1997) cited in Khayesi (1999) as follows:

Matatus do not follow the Highway Code, but the 'My Way Code'. They dawdle while touting for passengers and then make up for the delay by driving at breakneck speed between stops. They regularly break all speed limits. They pull out in front of traffic. They stop in the middle of the road, without pulling in to

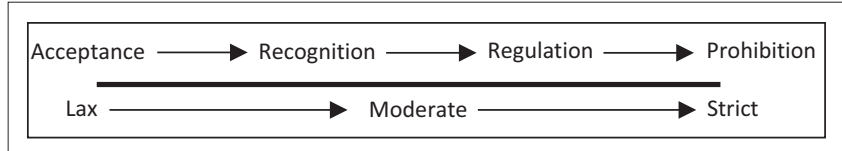

Source: Cervero, R., 2000, Informal transport in the developing world, United Nations Commission on Human Settlements, Nairobi, Kenya, 2000

FIGURE 1: Spectrum of public policy responses to informal public transportation.

the side. In fact, they stop anywhere in order to pick up or set down passengers, especially at roundabouts. They usually give no signals. They overtake on the inside and often use the verge instead of the road itself. They weave in and out of traffic, overtaking on hills and corners, ignoring right of way at roundabouts and road junctions, and violating the 'Keep Left' rule at traffic islands. They race other matatus, sometimes forming a line abreast across the road. (p. 9)

The foregoing description on matatus driver behaviour is not peculiar to the Kenyan context. It can be generalised to other IPT operations in sub-Saharan Africa, for example, Dala Dalas in Tanzania; Okadas in Nigeria and Kombis in Zimbabwe. Wilkinson (2008:1) raised an IPT driver behavioural characteristic when he says that IPT operations are often offered by poorly maintained and frequently unroadworthy vehicles, inappropriate and unsafe driver behaviour and fierce, often violent, competition between rival operators both for specific routes and for passengers on those routes. Similarly, Shittu (2014:77) has noted that the apparent overcompetition among operators has been noted to jeopardise safety of passengers, pedestrians and road furniture (Shittu 2013). Fierce and intense competition among operators, sometimes, leads to loss of lives, property and in some cases public disturbances. Competition induces drivers to engage in aggressive and dangerous diving behaviour, causing additional congestion and safety problems. Cervero and Golub (2007:446) subtly made an attempt to relate driver behaviour to the prevailing regulatory environment when they said '... many times informal services operate in a laissez-faire environment, prompting operators who survive on low profit margins to actively, and sometimes dangerously, compete for customers ...' This gets expressed as stopping almost anywhere to board passengers, overloaded vehicles and unsafe driving habits - what economists call 'collectively damaging behaviour' and termed in Latin America, la Guerra del Centavo 'the war for the cent'.

The foregoing literature survey faintly touches on how laissez faire approaches to IPT by regulating authorities may provoke unlimited supply of IPTs which, in turn, induces stiff competition which cascades down to aggressive driver behaviour. Lack of scholarly work on this conceptualisation 
has led to ineffective policy instruments when dealing with IPT driver behavioural issues. In order to deal with the above-mentioned driver behavioural issues from IPT, developing countries governments have attempted a range of policy interventions and these range from acceptance to prohibition, representing different degrees of regulatory stringency from lax to strict (Golub 2003). Different regulatory approaches have resulted in different outcomes (expected and unexpected) in different country settings. Absent in literature is how these policy interventions could themselves become explanatory variables to such driver behaviour.

Literature on the history of urban public transport in developing countries indicate that both national and local governments have shifted their policy stance from laissez faire to more stringent control or regulation (Cervero 2000; Gwilliam 2000; Kumar et al. 2016). This shifting policy produced what Gwilliam (2000) term, 'the regulatory cycle' of urban public transport in developing countries. This cycle chronicles the cyclical nature of the control of urban public transport that took place in former British or French colonies. Before independence, most colonies relied on privately owned bus services provided by the colonial power under franchised agreements. On achieving independence, some governments immediately nationalised the expatriate companies, whilst others simply reasserted and strengthened the regulatory powers. Through their socialist political ideologies, most governments felt the necessity to implement and enforce strict controls on fares in the interests of the public (passengers).

Because of this new operational environment, some expatriate companies discontinued operations, whilst some adjusted to the demands. Those that continued operations eventually were forced out of business because of the structural adjustment programmes (SAPs) widely adopted in different countries. SAPs ushered in a deregulated transport market wherein there was free market entry to the urban transport market. Further, the bus companies were no longer entitled to national subsidies. Eventually, cash starvation and stiff competitions drove most of the traditional large companies in Africa to bankruptcy (Gwilliam 2000).

The current urban public transport policy environment in Zimbabwe is basically at level 3 of the post-colonial regulatory cycle that is informal fragmented supply. This can be well understood when one traces back to the macro-economic policies adopted by the Government of Zimbabwe (GoZ) between 1990 and 2000. First was the economic SAP (ESAP) implemented in many developing countries in the early 1990s. In 1991, the GoZ proposed a policy agenda that formed the basis for the ESAP.

The World Bank and IMF supported the ESAP with a $\$ 125$ million structural adjustment loan (SAL) and a \$50m structural adjustment credit (SAC), both approved in 1992 and closed in 1993. ${ }^{1}$ The ESAP sought to transform 1.World Bank Group (2012), Independent Evaluation Group (IEG); Structural Adjustment and Zimbabwe's Poor.
Zimbabwe's tightly controlled economic system to a more open, market-driven economy. The restructuring sought to promote higher growth and to reduce poverty and unemployment by (1) reducing fiscal and parastatal deficits and instituting prudent monetary policy, (2) liberalising trade policies and foreign exchange system, (3) carrying out domestic deregulation and (4) establishing social safety net and training programmes for vulnerable groups. In line with goal (3) on domestic deregulation, the GoZ partially deregulated the urban transport sector in August 1993 allowing privately operated 'commuter omnibuses' (kombis) to compete with the then monopoly Zimbabwe United Passenger Company (ZUPCO).

The second macro-economic reform program was the Zimbabwe Programme for Economic and Social Transformation (ZIMPREST), which again emphasised deregulation and increased private sector participation in the national economy. Because of increasing demand for public passenger transport service, competing priorities and growing budgetary constraints, government realised that it could not continue to own and finance investment in transport infrastructure and services. Competition rather than control was seen as a better alternative in solving transport woes.

The deregulation and/or liberalisation of the transport sector in the early 1990s included ending of ZUPCO's urban public transportation monopoly in 1993, which facilitated the entry into the transport market of mainly indigenous entrepreneurs. It must be noted that, in principle, the government partially deregulated the sector as it was aware of the merits and demerits of deregulation. Some of the demerits experienced globally in cities such as Santiago (Chile), Delhi (India) and Nairobi (Kenya) include effects on environment, increased fares, increased air and noise pollution, traffic safety and traffic congestion. However, studies conducted by Maunder and Mbara (1995) have shown that the partial deregulation goal was never achieved; it was full deregulation from the onset. Following the liberalisation process, there was a rapid growth in both the number and variety of kombis fleet and the total public transport passenger carrying capability in Harare. The Traffic Management Local Subject Plan 1997 concurs with Maunder and Mbara (1995) when it states that ESAP made it easier to obtain vehicles for both private and public transport purposes than was the case only a few years ago. Table 2 illustrates on the increase in kombis omnibuses over the years.

The government's direct involvement in the provisioning of urban public transport somehow compromised its regulatory role. This was further aggravated by the prescribed deregulation exercise which saw multiple operators in the public transport sector. Politically, it was difficult for the government not to deregulate its transport market because deregulation was one of the conditions to access the $\$ 125 \mathrm{~m}$ SAL and a $\$ 50 \mathrm{~m}$ SAC. With the deregulation exercise, government directly induced competitors to itself. Thus, during 1994, two surveys were undertaken the first 5 months 
TABLE 2: Modal split throughout Harare (percentage).

\begin{tabular}{|c|c|c|c|c|c|c|c|c|}
\hline Year & ZUPCO stage bus & Emergency taxi & Commuter omnibus & Metered taxi & Motor car or cycle & Walk & Other & Total \\
\hline 1988 & 18 & 7 & - & 0.5 & 30 & 42 & 1 & 100 \\
\hline 1991 & 24 & 10 & - & 1.0 & 16 & 45 & 3 & 100 \\
\hline 1992 & 31 & 9 & - & 1.0 & 17 & 36 & 1 & 100 \\
\hline 1993 & 23 & 18 & 1 & 1.0 & 16 & 38 & - & 100 \\
\hline 1994 (January) & 25 & 18 & 4 & 1.0 & 14 & 35 & - & 100 \\
\hline 1994 (December) & 20 & 9 & 16 & 0.5 & 14 & 34 & 1 & 100 \\
\hline
\end{tabular}

Source: Maunder, D.A.C. \& Mbara, T.C., 1995, The initial effects of introducing commuter omnibus services in Harare, Zimbabwe, Department of Transport, TRL 123, Transport. Research Laboratory, Crowthorne, p. 4

after the legal introduction of kombis and the second 13 months later. During the January 1994, survey commuter omnibuses had 'captured' $4 \%$ of the market, emergency taxis had stabilised at $18 \%$ and ZUPCO had marginally increased to $25 \%$. By September 1994, commuter omnibuses had increased their share to $16 \%$, the emergency taxi share had diminished by half to $9 \%$ and the ZUPCO share had declined to $20 \%$. The emergency taxis instituted under the presidential decree of 1983 were subsequently phased out in 1997. The ZUPCO stage bus which once dominated the urban transport market fell by the wayside owing to reduced subsidies and unregulated competition from kombis and emergency taxis.

At the present moment, kombis have captured approximately $99 \%$ of the urban public transport sector in Zimbabwe and the other $1 \%$ is covered by pirate taxis and metered taxis. This is despite the position that the Zimbabwe National Transport Policy (2012) seeks to promote the use of high-capacity transport modes such as conventional buses and gradually phasing out kombis with a capacity of less than 26 seats. The transport policy further seeks to introduce controlled deregulation on highdemand routes through competitive tendering. The issue of competitive tendering has not been implemented up to now and neither are there any action plans on how this is to be carried out.

Posing a serious cut-throat competition to the kombis is a rampant increase in pirate taxis (Light Motor Vehicles) that operate from incidental bus termini in Harare, these illegal passengers pick up and drop off sites are locally known as 'mushikashika'. Pirate taxis offer the advantages of a small car in public transport as they quickly fill up and offer the highest degree of manoeuvrability because they disregard traffic rules and therefore have a quicker turnaround time as compared to kombis. Despite these advantages, pirate taxis are both informal and illegal as they are not recognised at law as a form of urban public transport. These do not have any documentation as expected for any public service vehicle in Zimbabwe. 'Passengers' using pirate taxis do so at their own risk. Figure 2 and 3 show the kombi and the pirate taxis operating in Harare. The relationship between these two modes of IPT in Zimbabwe is not complementary but that of damaging competition.

Today, most developing economies public transport systems are at stage (3) as depicted in Figure 4, that is, served by

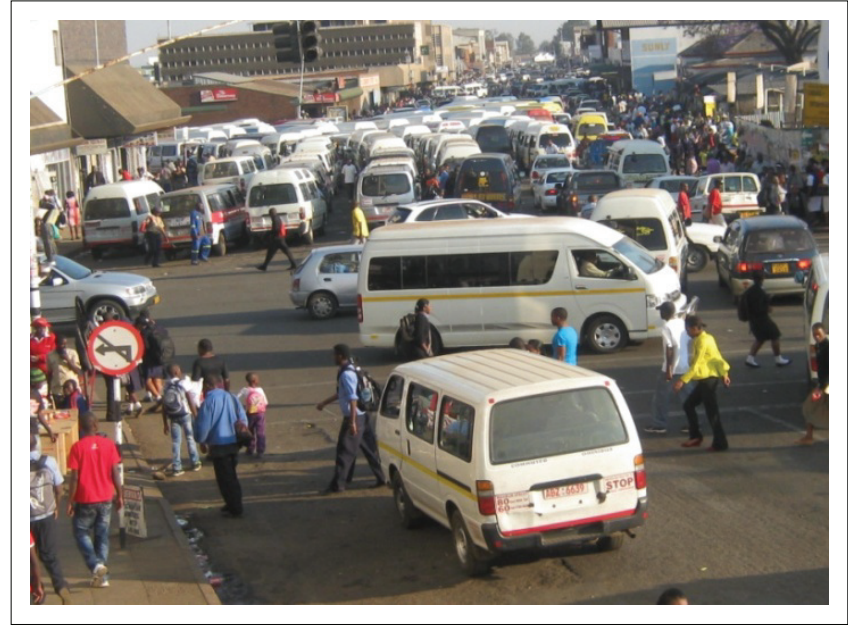

Source: Photo taken by Smart Dumba

FIGURE 2: Kombis operating in Zimbabwean cities.

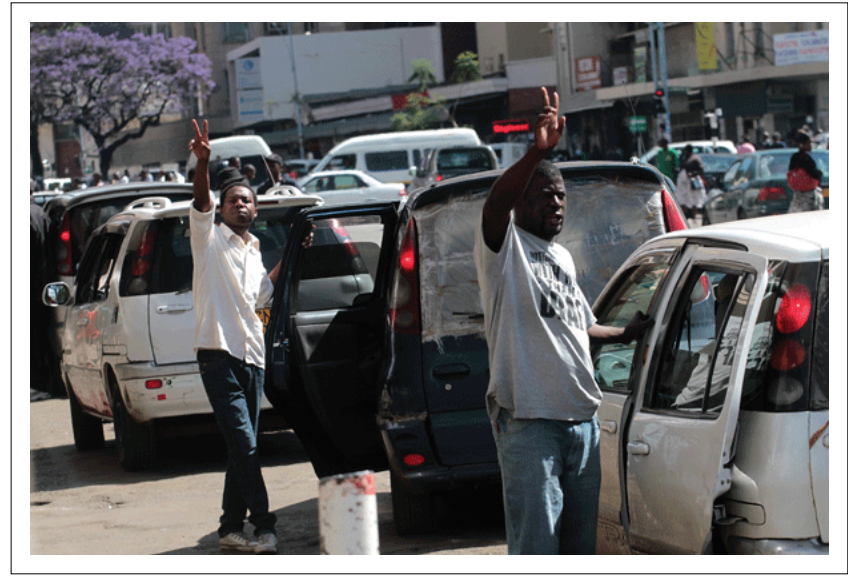

Source: Photo courtesy of Newsday Online, 21 May 2016, viewed 06 June 2017, from https:// www.newsday.co.zw/2016/05/21/touts-seek-divine-intervention

FIGURE 3: Pirate taxis operating in Zimbabwean cities.

privately owned small capacity minibuses or paratransit which are largely informal. Figure 4 gives a schematic view of the regulatory cycle applicable to most developing countries including Zimbabwe.

A number of drivers to the above cycle are noted including but not limited to inefficient fare regulation, regulatory capture and corruption, structural change in the operating industry, the inherent advantages of the small vehicle and self-regulation (Gwilliam 2000). Most developing countries: Zimbabwe, Kenya, Tanzania, Ghana and Uganda are at stages (3) (fragmented informal supply) and (4) (informal sector cartel) of their regulatory cycle. 


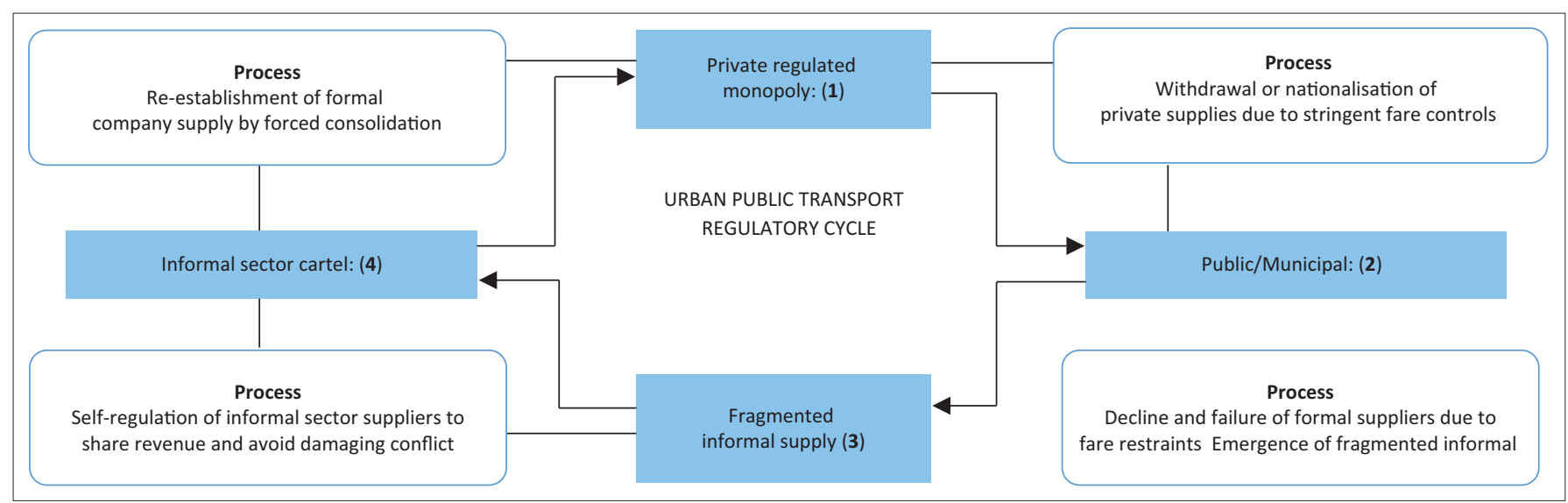

Source: Gwilliam, K.M., 2000, Public transport in the developing world - Quo Vadis? Discussion Paper TWU-39, Transport Division, The World Bank, Washington D.C, p. 5 FIGURE 4: The post-colonial regulatory cycle.

As discussed above, paratransit vehicles are known by different names in different parts of the world: Gbakas in Abidjan, Trotos in Accra, Magbanas in Conakry, Cars Rapides in Dakar, Daladalas in Dar es Salaam, Minibus taxis in Kampala, Matatus in Nairobi and Kombis in Harare. These vehicles' physical and dynamical properties are fairly not different from normal private cars. However, a key distinguishing feature is their driver behavioural characteristics. Scholars such as Shorter and Onyancha (1997), Golias and Karlaftis (2001), Golias (2003) and Xu et al. (2014) have discussed on the typical driver behaviour of IPT. Gunay (2007:129) gives a concise description of this behaviour which includes drivers having difficulty in staying in the lane, abrupt lane changes and driving on the shoulder. He further suggests that these can be grouped under the heading of 'lateral discipline of driving' or simply dangerous driving.

The typical behaviour of matatu (IPT in Kenya) drivers has been vividly captured by Shorter and Onyancha (1997: 87-88) below. This matatu driver behaviour can be generalised to many other paratransit modes in countries named above. Vassileva (1999) supports this by highlighting the inconvenience of the road and the traffic flows are determined to a large extent minibus drivers' behaviour in driving on the edge of and outside the carriageway:

... Matatus do not follow the Highway Code, but the 'My Way Code'. They dawdle while touting for passengers and then make up for the delay by driving at breakneck speed between stops. They regularly break all speed limits. They pull out in front of traffic. They stop in the middle of the road, without pulling in to the side. In fact, they stop anywhere in order to pick up or set down passengers, especially at roundabouts. They usually give no signals ... (Khayesi 1999:9)

\section{Methodology}

This study is based on a case study of IPT operations in Harare, the capital city of Zimbabwe. The study adopted a mixed-methods research paradigm, with much inclination towards qualitative. Johnson and Turner (2003) cited in Harwell (2011) have argued that the fundamental principle of mixed-methods research is that multiple kinds of data be collected with different strategies and methods in ways that reflect complementary strengths and non-overlapping weaknesses, allowing a mixed-methods study to provide insights not possible when only qualitative or quantitative data are collected. Put another way, mixed-methods research allows for the 'opportunity to compensate for inherent method weaknesses, capitalise on inherent method strengths, and offset inevitable method biases' (Greene 2007: xiii). This study has relied on a balance of literature, secondary reviews, empirical investigations and interviews of various stakeholders in examining the IPT driver behaviour and urban transport regulatory policy nexus. For both quantitative and qualitative data, the study mainly sought driver behavioural and regulation data from the three critical stakeholders of urban public transport in Zimbabwe: the general public (riders), operators and the regulating authorities (Harare City Council [HCC] 2015).

To ensure data robustness, the study gathered and triangulated both primary and secondary data. Primary data were elicited and compiled from informal conversations on driver behaviour with the passengers, drivers and operators of public transport. A 1-h field survey was also conducted to establish a scientific impact of IPT driver behaviour on the performance of traffic facilities. A convenient random sample of 30 passengers was selected from 10 major routes to and from the Harare Central Business District (CBD). With these selected passengers, the researcher conducted unstructured interviews with them in order to elicit their views on the contributing factors to kombi and pirate taxi driver behaviour and what they thought were the solutions. Complementing the data from passengers, the researcher conducted focus group discussions (FGDs) with the two largest commuter omnibus associations in Harare; these were the Zimbabwe National Commuter Omnibus Operators Organisation (ZNCOOO) and the Greater Harare Commuter Omnibus Operators Association (GHACO). With these associations, the researcher mainly sought data on their position as operators regarding 'their' drivers' driving behaviours, their relationship with the regulating authorities and their position 
on the best way to deal with dangerous driver behaviour. In depth, interviews were also conducted with the regulators, in this case, the HCC and the central government, through the Department of Physical Planning (DPP) under the Ministry of Local Government, Public Works and National Housing. A filed survey was also conducted to determine the design and operational capacities of the existing four bus termini in Harare.

Secondary data refer to data that were collected by someone else for another primary purpose (Johnston 2014:619). In this study, secondary data were sought from various urban public transport regulatory instruments that were instituted by the GoZ and HCC over the years. The study performed content analysis on the obtained policy documents. The sources that have been used to undertake the analysis include policy documents, published journal articles and reports from the HCC, the DPP and the National Archives of Zimbabwe. Specific documents included the Harare Combination Master Plan (1993), Traffic and Transportation Study Reports (1984, 1997), HCC Annual Reports, relevant city traffic by laws and statutes. As this study is concerned with connecting the driver behaviour and policy dots, this, it must be acknowledged, presents itself as an analytical challenge. Accordingly, about the best one can hope to do is weave together a disparate collection of anecdote, non-scientific surveys, interviews, field observations, and personal accounts - somewhat like looking at a jigsaw puzzle with half the pieces missing. After the assemblage of primary and secondary data, the researcher then applied the force field analysis to have an in-depth understanding of the pressures or factors creating and sustaining poor driver behaviour by IPT in Harare as well as regulatory measures in place to restrain such behaviour and their effectiveness.

\section{Study findings and analysis}

The following section presents and analyses the prevailing regulatory policy framework governing the urban public transport sector in Zimbabwe. After this, the article describes and explains on the typical dangerous driving behaviours exhibited by kombi and pirate taxi drivers as well the factors sustaining this behaviour. In the last sections, the article analyses those factors hindering effective IPT drier behaviour regulation and derive an IPT driver behaviour and regulation reinforcing loop diagram.

\section{Informal public transport driver behaviour in Harare}

Following the fully deregulated market within which kombis and pirate taxis are operating, there is relatively ease of entry and exit into the market. This coupled with weak institutional capacity to regulate the sector in terms of quality and quantity restrictions has resulted in the oversupply of public transport vehicles operating in Harare. An oversupply of kombis has on reasonable grounds, induced two forms of competition: space and operational. Competition for parking space is one characterised by drivers jostling for ranking space within the bus terminus. Here, the first in, first out rule applies; however, the smaller operators are normally outcompeted by old and well-established operators who elbow out new and small operators out of the passenger loading queue.

Operational competition is characterised by drivers overspeeding, cutting corners, red light and late amber running, tailgating and following too closely to the leading vehicle in a queue, driving in the inner lane of the opposing traffic and creation of artificial lanes during the peak periods, loading and dropping off passengers outside the designated bus termini. Creation of artificial bus termini around intersections induces serious bottleneck to traffic flow in the road network leading to recurrent traffic congestion. These operational characteristics are secondary effects of cut-throat competition caused by an oversupply of vehicles per given route per given time against limited ridership. Similar to kombis, pirate taxis drivers compete with a formal shuttle system operated by kombis for shorter inner CBD routes. These smaller vehicles virtually block traffic lanes as they pick up and drop passengers. Pirate taxis pick up and drop off passengers at intersections (signalised and unsignalised). An intersection approach with four approach lanes has two of the lanes blocked by the pirate vehicle scouting and shouting for passengers. This reduces the effective lane width and lane capacity and ultimately leading to intersection failure. During the evening peak hour, pirate taxi drivers become even more aggressive and block the whole intersection such that other local motorists are forced to look for alternative routes. This is the descriptive part of IPT driver behaviour, and the following sections attempt to proffer a scientific impact of this behaviour on traffic facilities' operational performances.

\section{The impact of informal public transport driver behaviour on modelling traffic facilities capacities}

The US Highway Capacity Manual (2000) contains different methodologies for analysing the capacity and level of service (LOS) for traffic facilities such as signalised intersections, unsignalised intersections, highways, freeways and so on. For all these facilities, the analysis must consider a wide variety of prevailing conditions, including the amount and distribution of traffic movements, traffic composition, geometric characteristics and details of intersection signalisation. The following section raises challenges posed by IPT drier behaviour in an attempt to conduct the analysis.

\section{Traffic characterisation problem}

Traffic planning literature classifies traffic into two main types: homogenous and heterogeneous traffic. The distinction between these two types of traffic is made for a methodological reason. Once one decides a mix is heterogeneous, certain assumptions can be applied to homogeneous mixes become irrelevant. Further, 
heterogeneous traffic mixes cannot be engineered using the same techniques that are necessary for homogeneous traffic mix analysis (Katz 2009:4). Homogenous traffic (mainly found in developed countries) is defined in the literature by Mallikarjuna and Rao (2011) as composed of identical vehicles and following the lane discipline. Katz has amplified the definition in 2009 and he said that traffic can be said to be homogenous when it has no variation in its operating speeds, size and driving character of its vehicles. Essentially, the homogenous traffic definitional attempt is based on the vehicles' identity in terms of their dynamical (speed, acceleration and deceleration) and mechanical (vehicle length, width, manoeuvrability, etc.) properties. Some scholars such as Katz (2009) and Praveen and Arasan (2013) further define homogenous traffic as that which constitutes at least $80 \%$ of private cars and the $20 \%$ is other modes. Fazio, Hoque and Tiwari (1999) in Katz (2009) suggest the value to be slightly higher at $85 \%$.

On the contrary, heterogeneous traffic (mainly found in developing countries) comprises vehicles of widely varying static and dynamic characteristics and the vehicles share the same road space without any segregation (Praveen \& Arasan 2013:302). Extreme cases of heterogeneous traffic compose of fast-moving and slow-moving vehicles or motorised and non-motorised vehicles. The motorised vehicles include cars, buses, trucks, auto-rickshaws (three wheelers), scooters and motorcycles (both two wheelers); and the non-motorised vehicles include bicycles, human-powered or cyclerickshaws, and animal-driven carts. The vehicles also vary in size, manoeuvrability, control and static and dynamic characteristics (Maini \& Khan 2000:258).
Traffic in Zimbabwe can arguably be classified as homogenous as it mainly constitutes of private motor vehicles and a small proportion of minibuses and pirate taxis. Despite this small proportionality of IPT, their driver behaviour introduces some heterogeneity characteristics (poor lane discipline) which make it very difficult for a traffic analyst to classify as homogenous. This scenario creates a traffic classification crises and thus making the choice of analytical approach difficult as to whether to treat the traffic as homogenous or heterogeneous.

\section{Lane geometrical configuration calibration challenges}

This is a challenge during the geometrical configuration phase of the analysis. An intersection as one shown in Figure 5 shows the ideal intersection configuration. However, because of the poor lane discipline of IPT, some traffic movements shown by arrows are violated. An intersection may have four lanes as shown with their respective traffic distributions. Rarely do minibus drivers follow these, instead they create artificial lanes that pose a serious model calibration challenge to a traffic analyst as he or she will be caught on a dilemma on either to use existing geometrical configuration of to incorporate the new artificial lanes. Traffic analytical tools such as SIDRA INTERSECTION would be incapacitated to function under such circumstances.

Further, lanes 3 and 4 (right turning movements) suffer hyper-congestion as shown in Figure 6. These drivers utilise lane number 2 designed to cater for through traffic and when they pass the stop line the turn right as shown below.

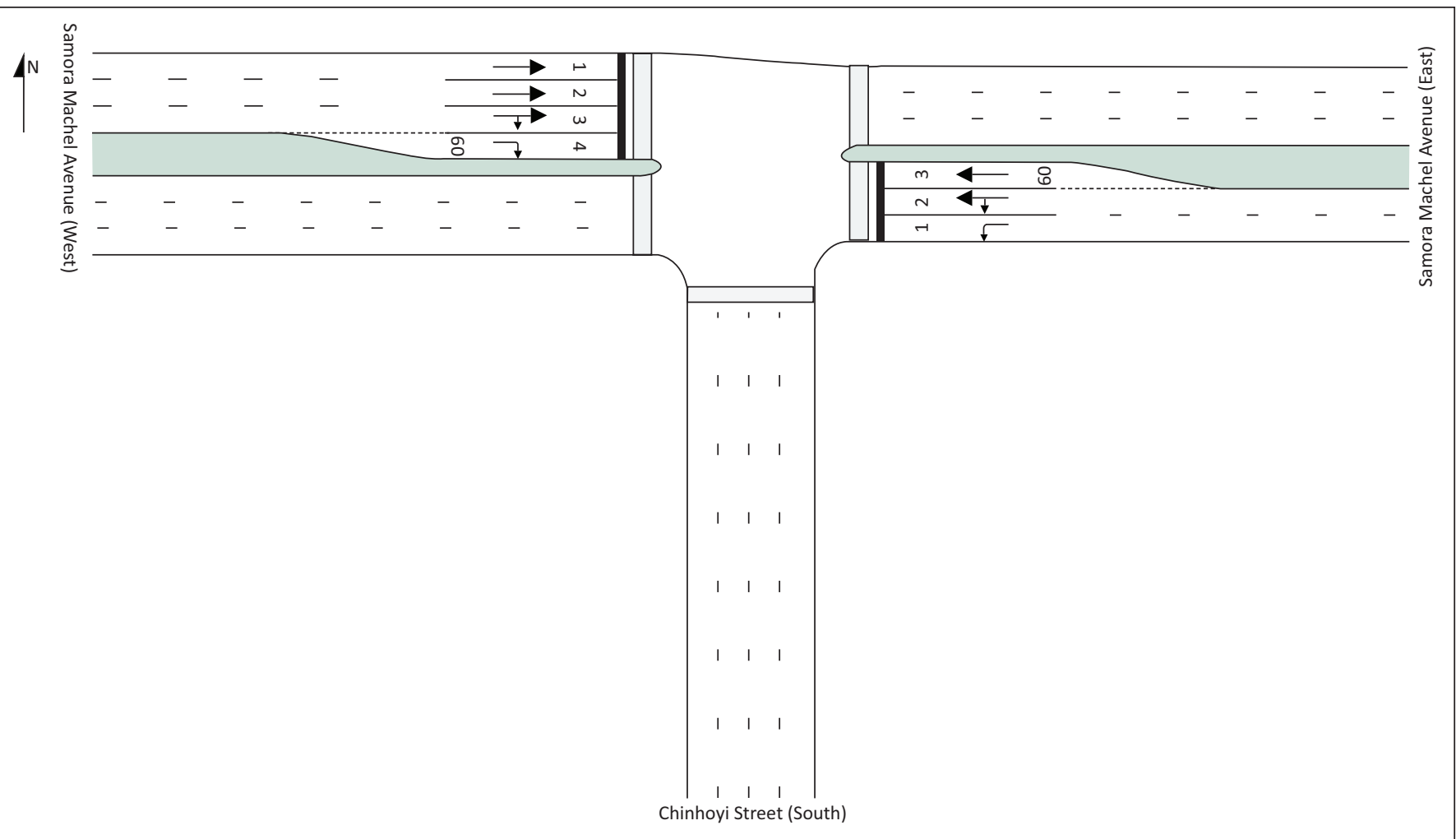

FIGURE 5: Geometrical configuration of surveyed intersection. 
This traffic overflow effect creates an artificial improved approach capacity. From a video clip taken, it was observed that lane 2 became a de facto right turn lane from 17:00 to 18:00 as the kombi drivers become more aggressive and misuse the geometric design of this lane.

Results from a 1-h traffic survey from 17:00 to 18:00 conducted on a Wednesday to establish the impact of IPT driver behaviour on intersection capacity, indicate that the capacity of the right turn lane groups is reduced because of the effect of high volumes of westbound through traffic, with an LOS of $\mathrm{D}$ as shown in Table 3. The LOS D shown in the table underestimates the quality of traffic flow on these two lanes. It appears that the lanes are performing fairly well, yet this is stemming from poor lane discipline and an adjusted turning radius particularly from kombi drivers. These drivers utilise lane number 2 designed to cater for through traffic and when they pass the stop line the turn right as shown below. This traffic overflow effect creates an artificial improved approach

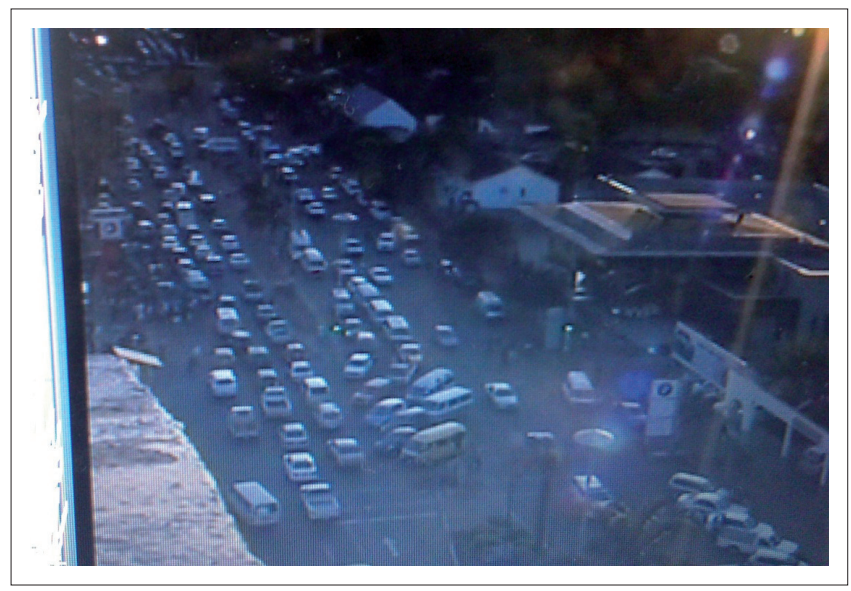

Source: Photo taken by Smart Dumba

FIGURE 6: Weekday oversaturated traffic conditions and driver behaviour on Samora Machel Avenue and Chinhoyi Street in Harare from 17:00 to 18:00. capacity. From the recorded video, it was observed that lane 2 became a de facto right turn lane from 17:00 to 18:00 as the kombi drivers abuse the geometric design of this lane.

\section{Factors sustaining informal public transport driver behaviour}

Extensive interviews conducted with operator organisations GHACO and ZNCOOO, the passengers and regulating authorities, HCC and the Ministry of Transport revealed three inextricably linked factors contributing to poor driver behaviour exhibited by kombi and pirate taxi drivers. These can be categorised as economic, regulatory and infrastructural.

\section{Economic meltdown}

The prevailing harsh macro-economic environment in Zimbabwe has pushed the majority of Zimbabwean populace into the unemployment and underemployment zones. With the declining agricultural and industrial production, it means many people are off the job market. Because transport is one of the remaining few industries that are performing well, it has become a safe hedge against unemployment for many unemployed youths. The unemployed youths find their way to the poorly regulated urban public transport sector and are employed or self-employ themselves. The former involves youths being employed by kombi operators as drivers and conductors. The latter involves a self-employment as touts or rank marshals and are paid $\$ 1$ per every fully loaded vehicle. Their job is simple; to shout to passengers directing them to a loading vehicle to their pre-known destinations. The unemployed and more often unlicensed drivers who approach kombi and pirate taxi owners alike and offer them relatively high daily revenue once they get employed. The vehicle owner is convinced of a high return than the law abiding driver who is licensed and has more to protect than the unlicensed one. The unlicensed driver operates without any predefined route and bus terminus. This very dangerously

TABLE 3: Intersection operational performance results.

\begin{tabular}{|c|c|c|c|c|c|c|c|c|c|c|c|c|c|}
\hline \multirow{2}{*}{$\begin{array}{l}\text { Lane use and } \\
\text { performance }\end{array}$} & \multicolumn{2}{|c|}{ Demand flows } & \multirow{2}{*}{$\begin{array}{c}\text { Cap. } \\
\text { (veh/h) }\end{array}$} & \multirow{2}{*}{$\begin{array}{l}\text { Deg. Satn } \\
\text { (v/c) }\end{array}$} & \multirow{2}{*}{$\begin{array}{l}\text { Lane util. } \\
(\%)\end{array}$} & \multirow{2}{*}{$\begin{array}{l}\text { Average } \\
\text { delay (s) }\end{array}$} & \multirow{2}{*}{$\begin{array}{l}\text { Level of } \\
\text { service }\end{array}$} & \multicolumn{2}{|c|}{$95 \%$ back of queue } & \multirow{2}{*}{$\begin{array}{c}\text { Lane } \\
\text { configuration }\end{array}$} & \multirow{2}{*}{$\begin{array}{l}\text { Lane length } \\
\qquad(\mathrm{m})\end{array}$} & \multirow{2}{*}{$\begin{array}{l}\text { Cap. adj. } \\
(\%)\end{array}$} & \multirow{2}{*}{$\begin{array}{l}\text { Prob. block. } \\
\text { (\%) }\end{array}$} \\
\hline & $\begin{array}{c}\text { Total } \\
\text { (veh/h) }\end{array}$ & HV (\%) & & & & & & Veh & Dist (m) & & & & \\
\hline \multicolumn{14}{|c|}{ East: Samora Machel Avenue (East) } \\
\hline Lane 1 & 322 & 1.6 & 584 & 0.552 & $77^{\mathrm{a}}$ & 29.4 & LOS C & 12.8 & 90.8 & Full & 100 & 0.0 & 0.0 \\
\hline Lane 2 & 496 & 3.2 & $690^{\mathrm{b}}$ & 0.719 & 100 & 20.1 & LOSC & 18.7 & 134.5 & Full & 100 & 0.0 & 32.0 \\
\hline Lane 3 & 385 & 3.2 & $536^{b}$ & 0.719 & 100 & 22.8 & LOSC & 16.4 & 117.7 & Short & 60 & 0.0 & 67.5 \\
\hline Approach & 1203 & 2.8 & - & 0.719 & - & 23.4 & $\operatorname{LOSC}$ & 18.7 & 134.5 & - & - & - & - \\
\hline \multicolumn{14}{|c|}{ West: Samora Machel Avenue (West) } \\
\hline Lane 1 & 166 & 2.8 & 619 & 0.268 & $32^{\mathrm{a}}$ & 7.1 & $\operatorname{LOSA}$ & 3.6 & 25.6 & Full & 100 & 0.0 & 0.0 \\
\hline Lane 2 & 359 & 2.8 & 1341 & 0.268 & $32^{\mathrm{a}}$ & 7.0 & $\operatorname{LOS} A$ & 7.6 & 54.2 & Full & 100 & 0.0 & 0.0 \\
\hline Lane 3 & 264 & 0.4 & 314 & 0.841 & 100 & 41.7 & LOS D & 12.0 & 84.0 & Full & 100 & 0.0 & 0.0 \\
\hline Lane 4 & 264 & 0.4 & 314 & 0.841 & 100 & 41.7 & LOS D & 12.0 & 84.0 & Short & 60 & 0.0 & 35.7 \\
\hline Approach & 1052 & 1.6 & - & 0.841 & - & 24.4 & LOS C & 12.0 & 84.0 & - & - & - & - \\
\hline Intersection & 2255 & 2.2 & - & 0.841 & - & 23.9 & LOS C & 18.7 & 134.5 & - & - & - & - \\
\hline
\end{tabular}

Level of service (LOS) method: delay (HCM 2000).

Lane LOS values are based on average delay per lane.

Intersection and approach LOS values are based on average delay for all lanes.

SIDRA Standard Delay Model is used. Control delay includes geometric delay.

Please note: Prob.block means probability of blockage, Lanes 2, 3 and Lane 4 show high degrees of probability of blockage due to kombi drivers.

Bold values of prob.block means high chances of lane blockage due to poor driver behaviour.

, Lane underutilisation determined by programme; ${ }^{b}$, Reduced capacity because of a short lane effect. 
fluid operation is associated with a higher revenue return per given day as compared to licensed drivers who normally operate from designated areas where there are longer waiting times before one carries the passengers. This supports the adage that, 'the higher the risk the higher the return'.

\section{Traffic enforcement regulatory policy loophole}

Operationally, the regulatory or policy factor revolves around issues to do with the differential approaches in which the traffic enforcement agents deal with kombis and pirate taxis. On the one hand, kombis are public service vehicles, and they are required, at law, to meet certain minimum operational vehicle and driver-related requirements. These include but limited to vehicle fitness certificate, defensive driving certificate, driver medical certificate, driver retest certificate obtainable from the Vehicle Inspectorate Department (VID). It is against these parameters that traffic enforcement agents inspect kombis and determine an appropriate fine in the event that either the driver or the vehicle lacks one of these. On the other hand, pirate taxis are no different from any other private vehicle because they all have the same yellow vehicle registration plates. Thus, at law, pirate taxis are regarded as private motor vehicles and as such public passenger laws and regulations cease to be applicable to pirate taxis. Ironically, pirate taxis will be operating parallel to kombis, exerting fierce competition particularly with registered shuttle kombis for inner city routes. Despite this, pirate taxis are not inspected of the necessary documentation expected of a public service vehicle. With this, kombi drivers have developed dangerous driving skills to evade traffic enforcement agents during times of raid as they are the ones prone to inspection than their counterparts (pirate taxi drivers).

\section{Inadequate and poorly maintained bus termini infrastructure}

There currently exist four major bus termini in Harare which were designed and constructed before the country's independence in 1980. These are Speke, Fourth Street, Charge Office and Market Square bus termini. During this time, the then Salisbury (Harare) did not witness any major public transport problems and the termini facilities would adequately accommodate the then ZUPCO buses which operated a scheduled service. With the advent of kombis post the deregulation period, there has not been a corresponding expansion and investment in the city's bus termini infrastructure to cater for an increase in the supply of kombis. Table 4 shows the termini capacity and other operational characteristics of kombis generated from a field survey.

By any standard, the design capacity across the four bus termini has since been outstripped by supply. Kombis were observed to be 'overspilling' onto adjacent road networks simply because they cannot be accommodated in the existing termini capacities. Even if one were to remove all unregistered kombis, still the number of registered operators is outstripping the termini design capacity (except for Fourth Street terminus). From the tables, it can be seen that the average dwell time $(3 \mathrm{~h})$ taken by kombis ranked in the terminus is too long which translate to reduced turnaround trips. Reduced turn around trips means reduced revenue. With this in mind, kombi drivers are forced to create additional incidental bus termini on intersections and mid-block road sections around the Harare CBD, scouting for passengers.

\section{Factors hindering effective informal public transport driver behaviour regulation in Harare}

The following sections present factors militating against effective IPT driver behaviour in Harare and these are conflicting institutional overlaps, legislative loophole in traffic enforcement, critical shortage of resources inadequate, political interference and policy dilemma.

\section{Urban transport conflicting institutional overlaps}

Urban public transport in Zimbabwe is controlled by both the central and local governments. Currently, about five ministries are responsible for administering the transport sector in one way or another. These are the ministries of:

- Transport, Communications and Infrastructural Development (legislation, transport policy, vehicle inspection, registration, licensing and enforcement of vehicle regulations).

- Local Government, Public Works and National Housing (MoLG, PW and NH) (urban public transport policy).

- Energy and Power Development (pipeline transport, energy and fuel policy).

- Finance through the Zimbabwe Revenue Authority (ZIMRA) (vehicle clearance at the border post, collection of tolling fees and import duty on imported vehicles and spare parts).

- Home Affairs (enforcement of traffic regulations).

The high number of kombis without valid operator's permits as shown across the four bus termini in Harare is indicative of institutional failure to regulate urban public transport sector. Though local governments are body corporate, they owe their existence to the statutes and central government that define their powers responsibilities and functions. In Zimbabwe, the relationship between the HCC and the Ministries of Transport and Ministry of Local Government is one characterised by duplication of duties and responsibilities as well as a top down decision process. For example, section 193 of the Urban Councils Act (Chapter 29) of 1996 clearly outlines that:

Notwithstanding anything to the contrary contained in the Road Motor Transportation Act [Chapter 13:10] or in this Act, the Minister may, whenever he considers it to be in the interests of the inhabitants of a council area, enter into agreements with, and grant permits to, persons to provide commuter transport services within a council area or between two or more council areas and, in so doing, he may make regulations to provide for -

1. The issuing of permits to such persons;

2. The control and regulation of fares;

3. The designation of appropriate routes;

4. The number of operators permitted on each route;

5. The period of validity of permits; 
TABLE 4: Harare termini capacity and other kombi operational characteristics.

\begin{tabular}{|c|c|c|c|c|c|}
\hline $\begin{array}{l}\text { Route name from Harare } \\
\text { CBD to }\end{array}$ & $\begin{array}{c}\text { Total number of } \\
\text { kombis }\end{array}$ & $\begin{array}{l}\text { Number of kombis with } \\
\text { valid permits }\end{array}$ & $\begin{array}{l}\text { Number of kombis } \\
\text { without permits }\end{array}$ & $\begin{array}{l}\text { Average number of } \\
\text { trips per day }\end{array}$ & $\begin{array}{l}\text { Average time spent parked at the } \\
\text { terminus (dwell time) in hours }\end{array}$ \\
\hline \multicolumn{6}{|c|}{$\begin{array}{l}\text { Name of bus terminus: Speke Avenue } \\
\text { Terminus design capacity: } 170 \\
\text { Prevailing terminus capacity (vehicle parked in the terminus per given time): } 250 \\
\text { Total number of kombis utilising the terminus: } 523\end{array}$} \\
\hline Warren Park 1 and 2 & 94 & 8 & 86 & 3 & 2 \\
\hline Warren Park D & 36 & 11 & 25 & 5 & 2 \\
\hline Green croft & 67 & 19 & 48 & 4 & 4 \\
\hline Kuwadzana 1-7 & 48 & 6 & 42 & 4 & 3 \\
\hline Dzivarasekwa & 39 & 10 & 29 & 4 & 3 \\
\hline Mbare & 50 & 16 & 34 & 5 & 2 \\
\hline Granary & 31 & 8 & 23 & 3 & 4 \\
\hline Marlborough & 32 & 12 & 20 & 3 & 3 \\
\hline Crowbrough & 8 & 3 & 5 & 4 & 2 \\
\hline Belvedere & 18 & 6 & 12 & 5 & 3 \\
\hline Kuwadzana Ext & 12 & n.a. & n.a. & 4 & 3 \\
\hline Total & 523 & 175 & 330 & - & - \\
\hline
\end{tabular}

\section{Name of bus terminus: Fourth Street}

Design terminus capacity: 580

Prevailing terminus capacity: 451

Total number of kombis utilising the terminus: 640

\begin{tabular}{|c|c|c|c|c|c|}
\hline Shamva & 40 & 26 & 14 & 1 & 5 \\
\hline Ruwa & 70 & 44 & 26 & 3 & 3 \\
\hline Msasa Park & 45 & 27 & 18 & 4 & 2 \\
\hline Mbare & 43 & 21 & 22 & 3 & 3 \\
\hline Chikurubi or support & 30 & 14 & 16 & 3 & 3 \\
\hline Mtoko or Mrewa & 55 & 26 & 29 & 1 & 6 \\
\hline Mabvuku or Tafara & 70 & 29 & 41 & 4 & 2 \\
\hline Hatcliffe or Borrowdale & 75 & 38 & 37 & 4 & 1 \\
\hline Chishawasha & 45 & 21 & 24 & 2 & 3 \\
\hline Epworth & 30 & 09 & 21 & 3 & 2 \\
\hline Acturus & 25 & 19 & 06 & 3 & 3 \\
\hline Domboshawa & 40 & 14 & 26 & 2 & 4 \\
\hline Damafalls & 52 & 27 & 25 & 3 & 3 \\
\hline Chisipiti or highlands & 20 & 15 & 05 & 4 & 3 \\
\hline Total & 640 & 330 & 310 & - & - \\
\hline
\end{tabular}

Name of bus terminus: Charge Office

Terminus design capacity: 135

Prevailing terminus capacity (vehicles parked per given time): 240

Total number of kombis utilising the terminus: $\mathbf{9 4 7}$

\begin{tabular}{lcccc} 
Sunningdale & 197 & 101 & 96 & 6 \\
Seke & 253 & 144 & 109 & 6 \\
Zengeza & 138 & 93 & 45 & 3 \\
St Marys & 124 & 48 & 76 & 4 \\
Hatfield & 107 & 56 & 51 & 5 \\
Makoni & 128 & $\mathbf{7 8}$ & 50 & 3 \\
\hline Total & $\mathbf{9 4 7}$ & $\mathbf{5 2 0}$ & $\mathbf{4 2 7}$ \\
\hline
\end{tabular}

Name of bus terminus: Market Square

Design terminus capacity: 240

Prevailing terminus capacity: 341

Total number of kombis utilising the terminus: 1231

\begin{tabular}{|c|c|c|}
\hline $\begin{array}{l}\text { Route name from Harare } \\
\text { CBD to }\end{array}$ & $\begin{array}{c}\text { Total number of } \\
\text { kombis }\end{array}$ & $\begin{array}{l}\text { Number of kombis with } \\
\text { valid permits }\end{array}$ \\
\hline \multicolumn{3}{|c|}{$\begin{array}{l}\text { Name of bus terminus: Speke Avenue } \\
\text { Terminus design capacity: } 170 \\
\text { Prevailing terminus capacity (vehicle parked in the terminus per given time): } 250 \\
\text { Total number of kombis utilising the terminus: } 523\end{array}$} \\
\hline Narren Park 1 and 2 & 94 & 8 \\
\hline Narren Park D & 36 & 11 \\
\hline Green croft & 67 & 19 \\
\hline Nestgate & 81 & 14 \\
\hline Kuwadzana 1-7 & 48 & 6 \\
\hline zivarasekwa & 39 & 10 \\
\hline Mbare & 50 & 16 \\
\hline Granary & 31 & 8 \\
\hline Marlborough & 32 & 12 \\
\hline Crowbrough & 8 & 3 \\
\hline Belvedere & 18 & 6 \\
\hline Dzivarasekwa Ext & 7 & n.a. \\
\hline Kuwadzana Ext & 12 & n.a. \\
\hline Total & 523 & 175 \\
\hline \multicolumn{3}{|c|}{$\begin{array}{l}\text { Name of bus terminus: Fourth Street } \\
\text { Design terminus capacity: } 580 \\
\text { Prevailing terminus capacity: } 451 \\
\text { Total number of kombis utilising the terminus: } 640\end{array}$} \\
\hline Shamva & 40 & 26 \\
\hline Ruwa & 70 & 44 \\
\hline Msasa Park & 45 & 27 \\
\hline Mbare & 43 & 21 \\
\hline Chikurubi or support & 30 & 14 \\
\hline Mtoko or Mrewa & 55 & 26 \\
\hline Mabvuku or Tafara & 70 & 29 \\
\hline Hatcliffe or Borrowdale & 75 & 38 \\
\hline Chishawasha & 45 & 21 \\
\hline Epworth & 30 & 09 \\
\hline Acturus & 25 & 19 \\
\hline Domboshawa & 40 & 14 \\
\hline Damafalls & 52 & 27 \\
\hline Chisipiti or highlands & 20 & 15 \\
\hline Total & 640 & 330 \\
\hline \multicolumn{3}{|c|}{$\begin{array}{l}\text { Name of bus terminus: Charge Office } \\
\text { Terminus design capacity: } 135 \\
\text { Prevailing terminus capacity (vehicles parked per given time): } 240 \\
\text { Total number of kombis utilising the terminus: } 947\end{array}$} \\
\hline unningdale & 197 & 101 \\
\hline Seke & 253 & 144 \\
\hline Zengeza & 138 & 93 \\
\hline St Marys & 124 & 48 \\
\hline Hatfield & 107 & 56 \\
\hline Makoni & 128 & 78 \\
\hline Total & 947 & 520 \\
\hline \multicolumn{3}{|c|}{$\begin{array}{l}\text { Name of bus terminus: Market Square } \\
\text { Design terminus capacity: } 240 \\
\text { Prevailing terminus capacity: } 341 \\
\text { Total number of kombis utilising the terminus: } 1231\end{array}$} \\
\hline Budiriro & 300 & 167 \\
\hline
\end{tabular}

Budiriro 300

Glenview

72

29

Waterfalls

Karoi

Shamva

Southlea Park

D.D.F

Machipisa

Hopley

Guruve

Glen Norah

\section{1}

54

10

20

31

192

31

87

140

Norton

181

n.a., data not available. 
TABLE 4 (Continues...): Harare termini capacity and other kombi operational characteristics.

\begin{tabular}{|c|c|c|c|c|c|}
\hline $\begin{array}{l}\text { Route name from Harare } \\
\text { CBD to }\end{array}$ & $\begin{array}{c}\text { Total number of } \\
\text { kombis }\end{array}$ & $\begin{array}{l}\text { Number of kombis with } \\
\text { valid permits }\end{array}$ & $\begin{array}{l}\text { Number of kombis } \\
\text { without permits }\end{array}$ & $\begin{array}{l}\text { Average number of } \\
\text { trips per day }\end{array}$ & $\begin{array}{l}\text { Average time spent parked at the } \\
\text { terminus (dwell time) in hours }\end{array}$ \\
\hline Bindura & 27 & 19 & 08 & 1 & 6 \\
\hline Southerton & 30 & 14 & 16 & 3 & n.a. \\
\hline Total & 1226 & 631 & 595 & - & - \\
\hline
\end{tabular}

n.a., data not available.

6. The insurance of vehicles;

7. Environmental protection from fuel emissions and pollutants;

8. Speed and safety standards;

9. Any matter necessary or convenient for the regulation of such commuter transport services. (p. 15)

Despite this legal procedure, the HCC has complained that the Ministry of Transport is acting ultra vires (beyond the sanctioned powers) as it is issuing out operators licenses and route permits to prospective kombis without their consultation and input on whether there is need for such services (Chief Transportation Planner [Harare City Council] pers. comm., 23 May 2017). The Road Motor Transportation Act (Chapter 13:15) Part III Subsection 12 specifies that where a person has been issued with an operator's licence for the operation of a stage carriage service, he shall, before commencing the service, apply to the commissioner for the issue of a route authority authorising him to operate the service over a specific route. On several occasions, operators are piled on oversubscribed routes and the HCC is forced to rubberstamp the operators. The lack of consultation on part of the Ministry of Transport is partly justifiable on the grounds that the Road Motor Transportation Act (Chapter 13:15) part iii, which provides for the operation of passenger transport services gives this sole mandate to the Commissioner of Road Transport and is silent on the issue of consultation with the relevant local authority concerned. This kombi supply path has posed a serious externally induced regulatory challenge on the part of the HCC. In other words, the HCC is forced to regulate a sector that it does not have full control over, which is proving to be very difficult if not impossible. Furthermore, the Ministry of Finance through ZIMRA continues to allow the importation of public passenger vehicle in the form of kombis without liaison with the Ministry of Transport on whether there is need for more vehicles in the country. Thus, decisions on urban public transport are made in silos without proper coordination and consultation among regulatory authorities.

The nature of relationship between the central and local government regarding regulating public transport supports some scholarly discourse on the trilogy of power, politics and planning. According to Beyazit (2013), the idea of controlling cities and nations via planning is as old as the city-states, and further, Foucault (1976) notes that every political debate in the 18th century onwards included discussions on urbanism, architecture and facilities of common life. Yet, it is not only through planning or infrastructure that power becomes tangible but also through a range of political techniques (Castells 1997). Thus, the central government has a direct influence and control over local authorities in order to advance its vested interests in local government's administration.

\section{Legislative loophole in traffic enforcement}

Further crippling the regulatory capacity of the HCC is that the Municipal Traffic Laws Enforcement Act (Chapter 29) of 1961 does not confer the municipal traffic with arresting powers. The preamble of the act clearly reads:

An Act to facilitate the enforcement and administration of the law relating to road traffic and to vehicles on roads by providing for the punishment without prosecution of certain offences under by laws or regulations made by municipal councils; and to provide for other matters connected with or arising out of the foregoing. (p. 10)

According to the Chief Transport Planner at the HCC, kombis and pirate taxi drivers know about this legislative loophole and therefore are not likely to change their driver behaviour as the punishment is not deterrent enough to induce driver behavioural change. At law, the national police, under the Ministry of Home Affairs, is the one conferred with arresting powers of traffic offenders. However, the HCC has cited lack of support and sometimes willingness from the police to enforce traffic regulations. This institutional fragmentation has militated against IPT regulation.

\section{Acute shortage of resources}

Above discussed factors are exogenous, other endogenous factors affecting the regulation of IPT in Harare are related to an acute shortage of resources (financial and human). Planning for public transport at a citywide scale must be done within the framework of a wider Traffic Operations Management System (TOMS) (Framework). A TOMS is a comprehensive system for enabling the effective control of all aspects of traffic in a city including public transport planning. It is in essence a procedural system that is structured to optimise the functioning of a department which is tasked with traffic management. TOMS is an important conceptual framework for the management of city traffic which the consultants, Stanway Edwards Associates (1997), recommended as a starting point in the whole process of traffic management in Harare. There are six basic components which interactively form the TOMS, namely, organisational structure, workforce, procedures, standards, state-of-the-art equipment and comprehensive database. These form the requisite ingredients for the effective operationalisation of TOMS. Table 5 outlines the status of these five key aspects within the HCC's Traffic and Transportation Department.

Clearly, the Traffic Management Local Subject Plan sufficiently put forward proposals to effectively manage traffic flow and public transport in Harare, but this has not materialised and this is a serious threat to any meaningful IPT regulation. The situation has not changed significantly since then. 


\section{Political interference}

The Zimbabwe Local Government Policy Review Paper (2005:7) states that national political parties in Zimbabwe have a definite influence on how local authorities such as the HCC operate. It is a common and accepted practice that members of a council who belong to the same political party can caucus to predetermine how to debate and vote on major issues to be discussed in councils. Sanctions are imposed on members who renege from an agreed party position. It follows that all national political parties will attempt to push for their policies. It is when the ruling party pushes for implementation of its policies by an oppositioncontrolled council that challenges arise. The opposition in council insists that they have a mandate to generate and implement policy at that level for so long as it is not against national policy.

Currently, the HCC is under the custodianship of the opposition party, yet the parent ministry responsible for local government is under the ruling party. With this, sometimes, there is a deliberate attempt at creating chaos in Harare by the ruling party in order to discredit the opposition party. This explains the lax approach or sometimes government directives that promote the current chaotic state in the public transport sector. What makes the situation rather difficult on the part of planners who are supposed to the agency of change or challenge the central government through planning is that planning can never intervene directly in the urban processes it aims to structure and shape, but uses different intermediary systems, such as discursive, institutional and spatial systems, resulting exactly in such two things as policy documents, legal frameworks and built neighbourhoods (Marcus 2011).

\section{Urban public transport regulatory policy dilemma}

The GoZ is currently under a policy dilemma regarding urban public transport regulation. Whilst there might be a desire to replace the fully deregulated regime with some form of controlled deregulation or full regulation, the prevailing harsh macro-economic environment in Zimbabwe subtly promotes or favours a fully deregulated market. This type of market ensures free entry into the market and subsequently leading to an oversupply of vehicles. An oversupply of vehicles is mainly undesirable from an environmental or societal perspective (increased pollution, increased chances of accidents, etc.), however, desirable from an economic point of view. The IPT sector is subjected to numerous taxes which significantly contribute to the national fiscus. The figures below are more of the sector's budget estimates and potential based on experiences by operators. These were submitted to the Ministry of Finance and Economic development last year during the 2017 national budget consultations.

From Table 6, one can see that each commuter omnibus contributes a total amount of $\$ 13903$ annually to the national fiscus. This contribution is significant considering the poorly performing economy and this makes it difficult for the GoZ to 'do away' with the deregulated IPT market or introduce some restrictive or prohibitive market conditions associated with regulatory regimes as this may result in the loss of revenue. This partly explains a relaxed policy approach towards the sector despite its widespread socio-environmental negative externalities.

\section{Discussion on informal public transport driver behaviour and the regulatory policy linkage}

A force field analysis conducted in this study revealed complex web of mainly regulatory factors generating, exacerbating and sustaining the dangerous and undesirable IPT driver behaviour in Harare. The fully deregulated policy environment within which IPT is operating in Zimbabwe paralleled by a laisez faire approach by the central and local government alike in making concerted efforts at inducing meaningful control over the IPT sector has led to an unjustifiable supply of IPT vehicles against limited ridership and infrastructural capacities in Harare. Literally, the sector is under 'the law of the jungle'. This can be explained by the adage that the IPT sector has become a 'necessary evil'. This is so because there is a positive relationship between increased number of vehicles typical of any fully deregulated market and contribution to the national fiscus through tax.

An unprecedented supply of kombis and pirate taxis simulates dangerous driving behaviour typified by; the creation of incidental bus terminus on intersections and mid-block sections, driving in the opposite direction on oneway streets, picking up and dropping off passengers anyway along the arterial network. Ironically, the traffic enforcement agents are aggravating the driver behaviour problem in two ways. Firstly, the study revealed that some supposedly regulators or traffic enforcers are the actual owners of the

TABLE 5: Status of Traffic Operations Management System components in Harare City Council, Traffic and Transportation Department.

\begin{tabular}{|c|c|c|}
\hline Component & What it constitutes & Status at Harare City Council \\
\hline $\begin{array}{l}\text { Organisational } \\
\text { Structure (OS) }\end{array}$ & $\begin{array}{l}\text {-A dedicated database manager to manage the TOMS database. } \\
\text {-The OS must ensure that procedures are facilitated and all activities } \\
\text { take place in a cost-effective manner. }\end{array}$ & $\begin{array}{l}\text { In the period 1997-2003, the department had a sound organisational structure to } \\
\text { meet the management of traffic. However, from } 2003 \text { to } 2016 \text {, four out of five } \\
\text { traffic engineers left the department compromising the city's capacity to deliver. }\end{array}$ \\
\hline Workforce & $\begin{array}{l}\text { TOMS must be adequately staffed with well-qualified and experienced } \\
\text { personnel in the application of traffic and transportation theory. }\end{array}$ & $\begin{array}{l}\text {-At present, the department has numerous posts which need to be filled because } \\
\text { of skills flight. } \\
\text {-While traffic and transportation theory, practice and technology are evolving } \\
\text { rapidly, the few staff available is not keeping abreast with such developments. The } \\
\text { city's workforce levels are unacceptably low for the size of the city's operation. }\end{array}$ \\
\hline Procedures & $\begin{array}{l}\text { Intra- and interdepartmental coordination and administrative protocols } \\
\text { and procedures. There should be effective liaison and coordination } \\
\text { between all stakeholders involved in traffic planning and management. }\end{array}$ & $\begin{array}{l}\text { Currently, there is interdepartmental fragmentation and disharmony. For example, } \\
\text { some actions executed at the department are not communicated to other } \\
\text { agencies, for example, the traffic enforcement section. This leads to duplication of } \\
\text { effort and blame game. }\end{array}$ \\
\hline
\end{tabular}


TABLE 6: Estimated contribution of the informal public transport sector to the national budget.

\begin{tabular}{|c|c|c|c|c|}
\hline Cost description & Supplier & Annual unit price (USD) & Number of units & Total annual economic contribution (USD) \\
\hline Fuel $(30 L * 312 * \$ 1.23)$ & Fuel companies & 11513 & 8000 & 92104000 \\
\hline Presumptive Tax & Min of Finance & 700 & 8000 & 5600000 \\
\hline Payee & Min of Finance & 480 & 8000 & 3840000 \\
\hline Vehicle insurance & $\begin{array}{l}\text { Insurance Council of Zimbabwe or } \\
\text { Traffic Safety Council of Zimbabwe }\end{array}$ & 264 & 8000 & 2112000 \\
\hline Passenger insurance & ICZ & 236 & 8000 & 1888000 \\
\hline Route authority & RMT & 75 & 8000 & 600000 \\
\hline Vehicle licence & ZINARA & 60 & 8000 & 480000 \\
\hline Rank disc $(* 3)$ & City of Harare & 300 & 8000 & 2400000 \\
\hline VID fitness & Vehicle Inspectorate Division (VID) & 40 & 8000 & 320000 \\
\hline Vehicle radio license & ZBC & 30 & 8000 & 240000 \\
\hline Retest-medical & Doctors & 20 & 8000 & 160000 \\
\hline Route authority form & City of Harare & 100 & 8000 & 800000 \\
\hline Retest - defensive & TSCZ & 13 & 8000 & 104000 \\
\hline Operators' license & Road motor transportation & 42 & 8000 & 336000 \\
\hline VID garage report & VID & 20 & 8000 & 160000 \\
\hline Total direct contribution & - & USD13 903 & - & USD111 224000 \\
\hline
\end{tabular}

Source: Commuter Operators 2017 National Budget Consultations

pirate taxis and unlicensed kombis. This compromises their ability to discharge their duties effectively because of conflict of interest; a regulator cannot be an operator at the same time. Secondly, when an IPT driver is caught driving recklessly, the vehicle is impounded and will only be released after paying a fine $\$ 132$ to the HCC. This enforcement approach encourages recurrent dangerous driver behaviour because the focus is on a fiscal punishment and neither is it aimed at driver behavioural change nor on safety. Figure 7 illustrates how these described regulatory issues are related to dangerous IPT driver behaviour.

\section{Conclusion}

Poor IPT driver behaviour is related to the prevailing regulatory policy in a mutually reinforcing fashion. Politically motivated relaxed regulatory approaches coupled with weak institutional capacity provide an optimal environment for poor driver behaviour. Uncontrolled deregulation in Harare has prompted an oversupply of IPT vehicles against suppressed ridership demand. This, in turn, has induced destructive cut-throat intermodal (kombi to kombi and pirate taxi to pirate taxi) and intra-modal competition (kombi-pirate taxi). This has resulted in more aggressive and dangerous driver behaviour characterised by poor lane discipline, touting, tailgating and picking up and dropping off passengers at undesignated stations. Furthermore, multiple government ministries and agencies whose relationship with the local authorities is uncoordinated and fragmented militate against any meaningful IPT regulation.

The article concludes by stating that any sustainable policy intervention to curb or at least reduce the ills of the IPT sector in Zimbabwe and perhaps other developing countries at large has to scrutinise and address the prevailing regulatory policy framework first. Direct traffic enforcement approaches and interventions, fines, clamping and towing and placing of spikes underneath the vehicles will only yield insignificant results as long as the regulatory policy framework remains the same. The fragmented informal supply regulatory regime is the one bearing the unbecoming IPT driver behaviour at least in Harare.

\section{Recommendations}

The first three recommendations made in this article are short and the last two are long term in nature.

\section{Urgent need for controlled deregulation}

The urban transport liberalisation policy of 1993 has entailed a deliberate abolition of regulations and controls by relevant authorities in Harare who are in some cases are the operators. To ensure sanity and order prevail in the urban public transport sector, there is need for concerted effort at 'quantity' and 'quality' controls. In Harare, these are currently lacking and are not enforced resulting in chaos.

\section{Establishment of urban public transport regulatory impact analysis framework}

The central and local governments in Zimbabwe must develop a framework for evaluating the effectiveness of urban public transport regulation. Regulatory Impact Analysis (RIA) could be one such a tool helps governments to assess the impacts of regulation. With RIA in place, the central and local governments alike are able to examine and measure the likely benefits, costs and effects of new or existing regulation. The overall aim of RIA is to assist governments to make their policies more efficient. Currently, the Zimbabwean government appears to be in a policy dilemma regarding the most appropriate regulatory policy for urban public transport hence the laissez faire approach to the sector which has proved to be doing more harm than good.

\section{Development of an urban transport institutional database management system}

The fragmented nature of institutional organisations dealing directly and indirectly with urban public transport 


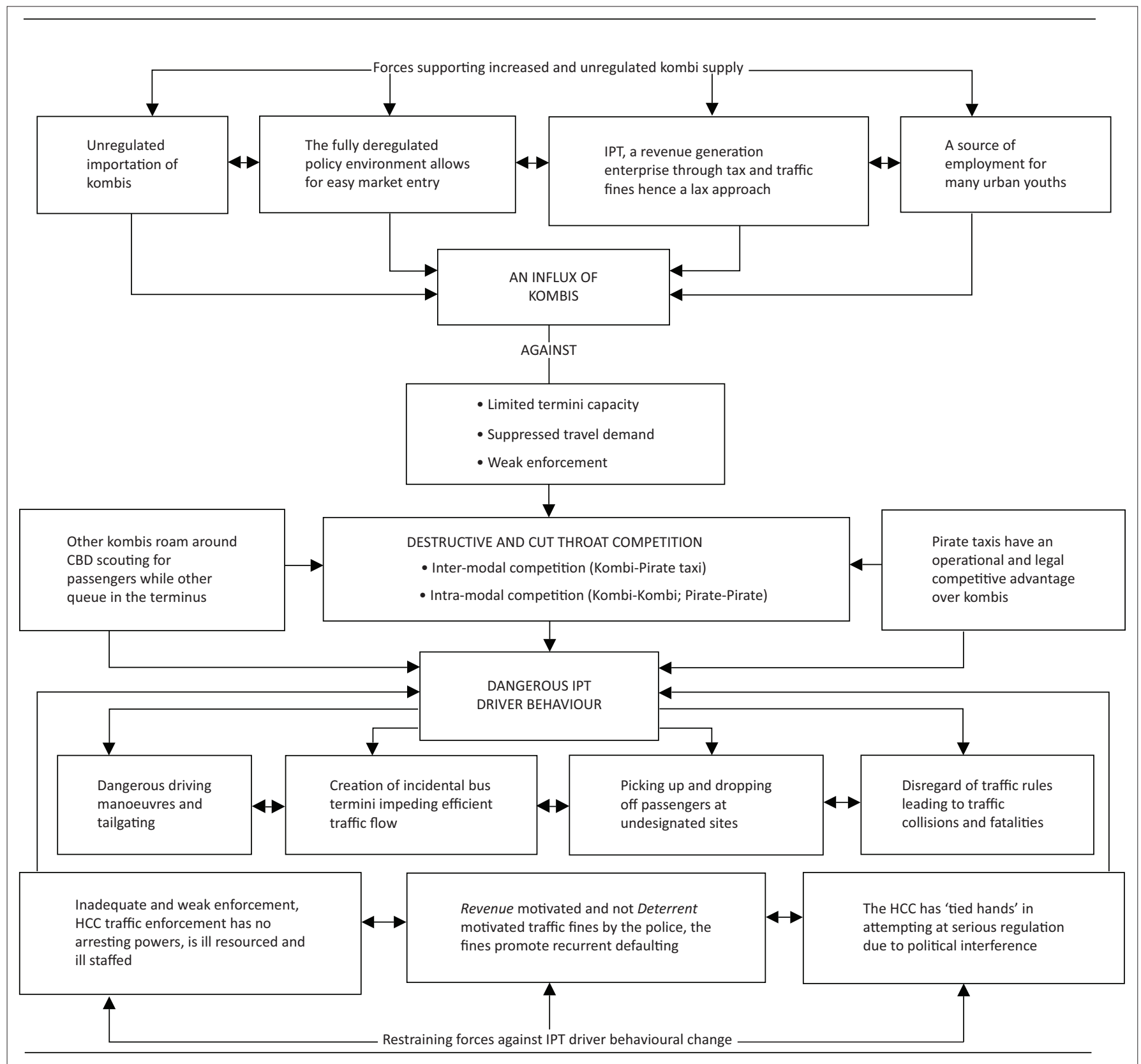

FIGURE 7: The informal public transport driver behaviour and regulatory policy reinforcing loop in Harare.

in Zimbabwe has in itself posed a serious coordination challenge and hindered against effective regulation of the sector. This coupled with the absent of computerised database management systems for enabling efficient and coordinated decision-making process makes regulation difficult. Currently, transportation decisions from various ministries and relevant government departments being done in silos, thus in the short term, there is an urgent need for the development of an institutional database management system for planning and regulating the urban public sector.

\section{Establishment of an autonomous Harare Metropolitan Planning Organisation}

In the long term, there is need for the establishment of an independent statutory body responsible for the regulation and management of the urban transport sector in Zimbabwe.
A Metropolitan Planning Organisation (MPO) is one such organisation. The MPO shall be an autonomous transportation policy-making body made up of representatives from local government and transportation agencies with authority and responsibility in metropolitan planning areas. The establishment of an MPO requires the enactment of a supportive legislation in order for it to be legitimate. For example, the United States passed its legislation on MPOs in the early 1970s. The MPO is envisaged to be a central body responsible for planning and regulating the urban public sector in Zimbabwe.

\section{Urban public transport policy should explore Integrated Public Transport}

The complex nature of urban IPT regulation in most developing countries, Zimbabwe, included owes to the 
complex socio-economic, institutional and regulatory environments found in those countries. This means that neither strict nor laissez faire regulatory policies for IPT are likely to maximise on social welfare and ensure sustainable urban mobility. Evidence from literature has demonstrated the not so sustainable nature of formal public transportation systems in the developing countries. Thus, a careful balance between formal and informal forms of public transport has to be struck, as neither of the two systems can operate on its own entirety. There exists a scope and possibility of exploring the concept of Integrated Public Transport (IPT) system. An IPT is a system that has ideally two or more forms of public transport; formal buses (local, feeder and transit) and commuter omnibuses (kombis) working together to adequately provide for the transport requirements of the town's or city's or region's populace. Other developing countries such as Kenya, Tanzania and Rwanda have made remarkable headways on IPT.

\section{Areas of further research}

The article has discussed IPT (kombis and pirate taxis) driver behaviour from a policy and regulatory perspective and exposed to the regulation-related difficulties when dealing with this behaviour and other operational characteristics. The study was a qualitative study and further studies could seek a deeper scholarly understanding of the IPT driver behaviour and regulatory linkage. The use of complexity theory could help in getting a deeper understanding of this issue. Feasibility studies on the possibilities of streamlining and capacity building of existing urban public transport institutions in Zimbabwe are urgent. Further, the article has revealed that the poor driver behaviour is mainly observed on traffic facilities such as intersections and road mid-block sections. Thus, there is need for an empirical investigation into the impact of IPT driver behaviour on the capacity and operational performance of traffic facilities such as intersections (signalised and unsignalised).

\section{Acknowledgements}

The author acknowledges the cooperation and data availed by the Harare City Council and Commuter Omnibus Operators Associations.

\section{Competing interests}

The author declares that he has no financial or personal relationships that may have inappropriately influenced him in writing this article.

\section{References}

Beyazit, E., 2013, 'Transport and socio-spatial inequalities: The case of the Istanbul Metro', Thesis submitted for the degree of Doctor of Philosophy, School of Geography and the Environment, University of Oxford.

Black, J., 2002, Critical reflections on regulation, Centre for Analysis of Risk and Regulation, London School of Economics, London.

Castells, M., 1997, The power of identity, Blackwell, MA.
CDIA, 2011, Informal public transportation networks in three Indonesian cities, Cities Development Initiative in Asia (CDIA), viewed 15 December 2016, from http:// www.cdia.asia/wp-content/uploads/Informal-Public-TransportationNetworks. pdf

Cervero, R., 2000, Informal transport in the developing world, United Nations Commission on Human Settlements, Nairobi, Kenya, 2000.

Cervero, R. \& Golub, A., 2007, 'Informal transport: A global perspective', Transport Policy 14, 445-447. https://doi.org/10.1016/j.tranpol.2007.04.011

Donnellan, T., Hanrahan, K. \& Hennessy, T., 2012, Defining an institutional framework for the labour market. Factor markets, Working Paper No. 24, viewed from https://www.ceps.eu/publications/defining-institutional-framework-labourmarket

Dye, T.R., 1987, Understanding public policy, 6th edn., Prentice-Hall, Englewood Cliffs, $\approx \mathrm{NJ}$.

Fazio, J., Hoque, M. \& Tiwari, G., 1999, 'Fatalities of heterogeneous street traffic', Transportation Research Record: Journal of the Transportation Research Board 1695, 55-60.

Foucault, M., 1976, 'Power', J.D. Faubion (ed.), Essential works of Foucault 1954-1984 Third Volume [1994], Penguin, London.

Freiberg, A., 2006, 'The tools of government and regulatory design', in Presentation to the Australasian Compliance Institute, Sydney, April 26, n.p.

Golias, J.C., 2003, 'Examining sensitivity of impact of taxi traffic on capacity and delays at urban road sections', Journal of Transportation Engineering 129(3), 286-291. https://doi.org/10.1061/(ASCE)0733-947X(2003)129:3(286)

Golias, J.C. \& Karlaftis, M.G., 2001, 'A methodology for assessing the impacts of specialized vehicles on the traffic stream', in Proceedings of the Transportation Research Board Annual Meeting, Transportation Research Board, Washington, $D C$, n.p.

Golub, A., 2003, 'Welfare analysis of informal transit services in Brazil and effects of regulation', PhD dissertation, Department of Civil and Environmental Engineering, University of California, Berkeley.

Government of Zimbabwe, 1961, Municipal Traffic Laws Enforcement Act, (Chapter 29:10), Government Printers, Harare.

Government of Zimbabwe, 1984, Traffic and transportation study report. Unpublished.

Government of Zimbabwe, 1993, Harare combination master plan, Government Printers, Harare.

Government of Zimbabwe, 1997, The Road Motor Transportation Act, (Chapter 13:15), Government Printers, Harare.

Government of Zimbabwe, 2012, The National Transport Policy, Government Printers, Harare.

Greene, J.C., 2007, Mixed methods in social inquiry, Wiley, New York.

Gunay, 2007, 'Car following theory with lateral discomfort', Transportation Research Part B 41, 722-735. https://doi.org/10.1016/j.trb.2007.02.002

Gwilliam, K.M., 2000, Public transport in the developing world - Quo Vadis? Discussion Paper TWU-39, Transport Division, The World Bank, Washington D.C., New York.

Harare City Council, 2015, Department of Urban Planning Services Annual Report. Unpublished.

Harwell, M.R., 2011, 'Research design in qualitative/quantitative/mixed Methods', in C.F. Conrad \& R.C. Serlin (eds.), Handbook for research in education: Pursuing ideas as the keystone of exemplary inquiry, pp. 147-182, Sage Publications, Thousand Oaks, CA.

Johnson, R.B. \& Turner, L.A., 2003, 'Data collection strategies in mixed methods research', in A. Tashakkori \& C. Teddlie (eds.), Handbook of mixed methods in social and behavioral research, pp. 297-319, Sage, Thousand Oaks, CA.

Johnston, M.P., 2014, 'Secondary data analysis: A method of which the time has come', Qualitative and Quantitative Methods in Libraries (QQML) 3, 619-626.

Kassa, F., 2014, 'Informal transport and its effects in the developing world: A case study of Addis Ababa, Ethiopia', Journal of Transport Literature 8, 113-133. https://doi.org/10.1590/S2238-10312014000200006

Katz, D., 2009, 'Heterogeneous traffic mixes', viewed 10 June 2017, from http://www. donaldkatz.com/CEE6603-TermPaper-HeterogeneousTraffic.pdf

Khayesi, M., 1999, 'The struggle for regulatory and economic sphere of influence in the Matatu means of transport in Kenya: A stakeholder analysis', paper presented at the Sixth International Conference on Competition and Ownership in Land Passenger Transport, Cape Town, South Africa, 19-23 September.

Kumar, M., Singh, S., Ghate, A.T., Pal, S. \& Wilson, S.A., 2016, 'Informal public transport modes in India: A case study of five city regions', IATSS Research 39(2), 102-109. https://doi.org/10.1016/j.iatssr.2016.01.001

Local Development Plan Number 22, Written Statement, 1996, Traffic management local subject plan, Draft Final Proposals Report for Local Plan 22 Area. Unpublished.

Losby, J.L., Else, J.F., Kingslow, M.E., Edgcomb, E.L., Malm, E.T. \& Kao, V., 2002, Informal economy literature review, ISED Consulting and Research \& The Aspen Institute, viewed 10 April 2017, from http://www.kingslow-assoc.com/images/Informal_ Economy_Lit_Review.pdf

Maini, P. \& Khan, S., 2000, 'Discharge characteristics of heterogeneous traffic at signalized intersections', in Proceedings of the Fourth International Symposium on Highway Capacity, Maui, HI, pp. 258-270.

Mallikarjuna, C. \& Rao, K.R., 2011, 'Heterogeneous traffic flow modelling: A complete methodology', Transportmetrica 7(5), 321-345. https://doi.org/10.1080/1812860 1003706078 
Marcus, L., 2011, 'Is planning past politics? Political displacements and democratic deficits in contemporary territorial governance. Planning is political but not politics - The need to identify and develop theory on planning media', paper presented at a Symposium at KTH Architecture and the Built Environment, 8-9 September. Sweden.

Maunder, D.A.C. \& Mbara, T.C., 1995, The initial effects of introducing commuter omnibus services in Harare, Zimbabwe, Department of Transport, TRL 123 omnibus services in Harare, Zimbabwe, Depart

Newsday Online, 21 May 2016, viewed 06 June 2017, from https://www.newsday. co.zw/2016/05/21/touts-seek-divine-intervention

Praveen, P.S. \& Arasan, V.T., 2013, 'Influence of traffic mix on PCU value of vehicles under heterogeneous traffic conditions', International Journal for Traffic and Transport Engineering 3(3), 302-330. https://doi.org/10.7708/ijtte.2013. 3(3).07

Shittu, A.O., 2014, 'Towards quasi-formal management of paratransit in informal transport dependent cities of Nigeria', IOSR Journal of Humanities and Socia Science (IOSR-JHSS) 19, 75-80.

Shorter, A. \& Onyancha, E., 1997, 'Matatu culture', in Secularism in Africa: A case study: Nairobi city, Paulines Publications Africa, Nairobi.

Stanway and Edwards, 1997, Traffic and transportation study for Harare City Council, Harare. Unpublished.
Syabri, I., Pradono, B. \& Soegijanto, T., 2013, 'Embracing Paratransit in Bandung metropolitan area, West Java, Indonesia', Case study prepared for Global Report on Human Settlements 2013, viewed 23 December 2015, from http://www. unhabitat.org/grhs/2013

The World Bank Group, 2012, Structural adjustment and Zimbabwe's poor, viewed 10 July 2015, from http://Inweb90.worldbank.org/oed/oeddoclib.nsf/DocUNIDView ForJavaSearch/15A937F6B215A053852567F5005D8B06

Transportation Research Board (TRB), 2000, Highway capacity manual, Special Report 209, National Research Council, TRB, Washington, DC.

Vassileva, L.D., 1999, 'Minibus operations along Lomagundi Road, Harare', paper presented at the International Conference Series on Competition and Ownership in Land Passenger Transport - 1999, Cape Town, South Africa, Thredbo 6.

Wilkinson, P., 2008, 'Formalizing Paratransit operations in African cities: Constructing a research Agenda', in Proceedings of the 27th Southern African Transport Conference, pp. 480-490. South Africa.

Xu, C.-C., Liu, P., Wang, W., Jiang, X. \& Chen, W., 2014, 'Effects of behavioural characteristics of taxi drivers on safety and capacity of signalised intersections', Journal of Central South University 21, 4033-4042.

Zimbabwe Institute, 2005, Local Government: Policy Review, viewed 08 April 2017 from www.kubatana.net/docs/.../zim_institute_loc_gvt_paper_0506.doc 